\title{
Doğrudan Yabancı Sermaye Yatırımlarının Belirleyicileri: Seçilmiş Doğu Asya ve Pasifik Ülkelerinden Ampirik Bulgular'
}

\author{
Harun BAL, Department of Economics, Faculty of Economics and Administrative Sciences, Cukurova \\ University, Turkey; e-mail: harunbal@cu.edu.tr
}

Emrah Eray AKÇA, Department of Economics, Faculty of Economics and Administrative Sciences, Cukurova University, Turkey; e-mail: eakca@cu.edu.tr

\section{Determinants of Foreign Direct Investments: Empirical Evidence from Selected East Asia and Pacific Countries ${ }^{2}$}

\begin{abstract}
In this study, the determinants of foreign direct investment was analyzed using the 2000-2013 period panel data for selected East Asian and Pacific countries (Australia, China, Indonesia, Philippines, South Korea, Hong Kong, Japan, Malaysia, Singapore, Thailand, New Zealand). Based on the related literature, market size, trade openness, macroeconomic stability, infrastructure, agglomeration effects and political stability had been determined as affecting factors of foreign direct investment. Our general findings from the study reveal that net foreign direct investment inflows depend on the market size, the agglomeration effects and the degree of trade openness. Therefore, it has recommended that the countries, which are aiming to increase the size of the net foreign direct investment inflows, should implement active policies increasing market size and the liberalization of trade practices.
\end{abstract}

Keywords $\quad$ : Foreign Direct Investment, Panel Data Analysis, East Asia and Pacific Countries.

JEL Classification Codes : $\quad$ C23, F21, F23.

\section{Öz}

Bu çalışmada, seçilmiş Doğu Asya ve Pasifik ülkeleri (Avustralya, Çin, Endonezya, Filipinler, Güney Kore, Hong Kong, Japonya, Malezya, Singapur, Tayland, Yeni Zelenda) için doğrudan yabanc1 sermaye yatırımlarının belirleyicileri, 2000-2013 dönemi panel verileri kullanılarak incelenmiştir.

$1 \quad$ This article is the revised and extended version of the paper presented in "First International Annual Meeting of Sosyoekonomi Society" which was held by Sosyoekonomi Society and CMEE - Center for Market Economics and Entrepreneurship of Hacettepe University, in Munich/Germany, on October 29-30, 2015.

2 Bu makale Sosyoekonomi Derneği ile Hacettepe Üniversitesi Piyasa Ekonomisini ve Girişimciliği Geliştirme Merkezi tarafindan Almanya'nın Münih şehrinde, 29-30 Ekim 2015 tarihlerinde düzenlenen "Birinci Uluslararası Sosyoekonomi Derneği Yıllık Buluşması”nda sunulan çalışmanın gözden geçirilmiş ve genişletilmiş halidir. 
Bal, H. \& E.E. Akça (2016), "Doğrudan Yabancı Sermaye Yatırımlarının Belirleyicileri: Seçilmiş

Doğu Asya ve Pasifik Ülkelerinden Ampirik Bulgular”, Sosyoekonomi, Vol. 24(30), 91-111.

İlgili literatürden yola çıkarak doğrudan yabancı sermaye yatırımlarına yön vermesi beklenen faktörler; piyasa hacmi, ticarete açıklık, makroekonomik istikrar, altyapı, yığılma etkisi ve politik istikrar olarak belirlenmiştir. Çalışmadan elde edilen genel bulgular, söz konusu ülkelere gelen net doğrudan yabancı sermaye yatırımlarının piyasa hacmine, yığılma etkisine ve ticarete açıklık derecesine bağlı olduğunu ortaya koymaktadır. Buna göre, söz konusu ülkelerin yurtiçine giren net doğrudan yabancı sermaye yatırımlarını artırmak için, piyasa hacmini ve ticarette serbestleşmeyi artırmaya yönelik aktif politikalar uygulamaları önerilmektedir.

Anahtar Sözcükler $\quad$ : Doğrudan Yabancı Sermaye Yatırımı, Panel Veri Analizi, Doğu Asya ve Pasifik Ülkeleri.

\section{Giriş}

Sınır ötesi yatırımlar global ekonominin en dikkat çekici özelliklerinden birisidir. Son yıllarda birçok ülke doğrudan yabancı sermaye yatırımları (DYSY)'nın istihdam, yatırım, verimlilik ve genel olarak iktisadi gelişme üzerindeki olumlu etkilerinden faydalanabilmek için açık kapı politikası uygulamaya başlamıştır. Ülkeler arasında rekabet ortamının da oluştuğu bu durumda hükümetler, temel ekonomi politikalarında bazı değişikliklere de gitmektedirler. Bu değiş̧ikliklerin önemli bir kısmı; yurtiçi iş gücü piyasa koşulları, kurumlar vergisi, tarife engelleri, sübvansiyonlar, özelleştirmeler ve düzenleyici rejim politikaları alanlarında görülmektedir. Mevcut literatürde DYSY'nin, ülkelerin gerek duyduğu sermayeyi sağlamasının yanında üretim, ihracat, istihdam ve verimlilik artışları sağladığına ve yönetim becerileri ile teknoloji transferi gerçekleştirdiğine vurgu yapılmaktadır (Resmini, 2000; Agiomirgianakis vd., 2003; Janicki \& Wunnava, 2004; Vijayakumar vd., 2010; Jadhav, 2012).

1990’lı yıllara gelindiğinde gittikçe hız kazanan globalleşme hareketleriyle birlikte, çok uluslu şirket (ÇUŞ)'ların faaliyetleri DYSY'ye farklı bir boyut kazandırmıştır. Bu döneme kadar yaygın olan bağımsız-firmalar arası ticaret, yerini ilişkili-firmalar içi ticaret gelişmelerine bırakmıştır. Bu gelişmeler, önce büyük ÇUŞ'ların üretim süreçlerini ve aşamalarını yerel avantajlardan yararlanmak için diğer ülkelerdeki bağımsız firmalara taşıması, sonrasında ise bu faaliyetlerini kendi birimlerini taşıyarak gerçekleştirmeleri şeklinde olmuştur. Bu faaliyetler genel bir ifadeyle DYSY olarak ele alınmakta ve ülkelerin ödemeler bilançolarında sermaye hareketlerinden izlenen verilerle araştırmalara konu olmaktadır. Mal ve hizmet ihracatındaki artış gibi DYSY'deki artışın ödemeler bilançosu üzerindeki etkisi de dış açık kapayıcı niteliktedir. DYSY ve ihracatın ödemeler dengesi ve dolayısıyla ülke ekonomisi üzerindeki bu olumlu etkilerine rağmen, bu faaliyetlerin gerçekleşip gerçekleşmemesi yine de tartışılır durumdadır. Bu tartışmaların bir kısmı DYSY ve ihracat arasındaki ikame ya da tamamlayıcılık ilişkisi üzerinde dururken; diğer bir kısmı DYSY ve ekonomik gelişme ilişkisi üzerinde durmaktadır.

DYSY'nin üretim ya da ihracat ile kıyaslandığında daha fazla bölgesel yoğunlaşma eğiliminde olduğu gözlenmektedir. Bu eğilim 1990'lara kadar gelişmiş ülkelerde yoğunlaşma biçiminde iken, 1990'lı yıllarla birlikte küresel üretim siteminde artan paylarıyla ilişkili olarak gelişmekte olan ülke (GOÜ)'lere kaymaya başlamıştır. Bu açıdan GOÜ’ler içinde Asya bölgesi ilk sırada yer almaktadır. Özellikle, Asya bölgesinde küresel üretim ve ihracat platformu görünümünde olan Çin, gerçekleşen reformlar sayesinde 1990'lı 
yıllarla birlikte DYSY'nin bir cazibe merkezi haline gelmiştir. Bu durum diğer ülkeler için bir sermaye çıkışı ya da sermaye girişinde bir azama ile sonuçlanmıştır. Bu nedenle birçok sanayileşmiş ülkede maliyet ve ücret düşüşü yönünde bir baskı oluşurken, birçok ülkede DYSY'yi yurt içine çekici faktörlerin geliştirilmesi gerekliliği daha da belirginleşmiştir (UNCTAD, 2013).

Seçilmiş Doğu Asya ve Pasifik ülkeleri için DYSY'nin belirleyicilerinin analiz edildiği bu çalışmanın geri kalanı şu şekilde organize edilmiştir: İkinci bölümde DYSY ile ilgili teorik bilgilere değinildikten sonra, üçüncü bölümde konuyla ilgili ampirik literatür özeti sunulmaktadır. Veri seti, metodoloji ve ekonometrik modelin yer aldığı dördüncü bölümün ardından beşinci bölümde ampirik bulgular ortaya koyulmaktadır. Çalışmamız, sonuçlar ve bu sonuçlara ilişkin değerlendirmelerin yer aldığı altıncı bölüm ile tamamlanmaktadir.

\section{Doğrudan Yabancı Sermaye Yatırımları}

DYS yatırımları kısaca, hisse ya da oy hakkında en az yüzde 10 oranında yurtdışı yerleşiklerin payı olan girişimler olarak tanımlanmaktadır. Uluslararası sermaye akımlarının önemli bir parçası olan DYSY, mali kaynakların dışında, üretime yönelik bina ve fabrika gibi fiziki üretim araçlarına yapılan yatırımlardan oluşmaktadır. DYSY, çok uluslu şirketler (ÇUŞ) tarafından yapılmaktadır. ÇUŞ, iki veya daha fazla ülkede üretim ve/veya pazarlama faaliyetlerini yürüten, kendisine ait işletme stratejisi, yönetim anlayışı olan ve bu stratejileri tüm bağlı kuruluşları ve şubelerinde uygulayan işletmeler şeklinde tanımlanmaktadır. ÇUŞ'lar, pazara nüfus etmek, hammaddelere erişim, ara girdilere erişim, işgücü maliyetlerini azaltmak, teknolojiye erişim, vergi yükünü azaltmak, gümrük engellerini aşmak, yatırımlarını uluslararası boyutta çeşitlendirmek ve ulaştırma maliyetlerini aşmak gibi sebeplerle DYSY'ye yönelmektedir (IMF, 2004).

DYSY'nin çeşitli türleri bulunmaktadır. Bunlardan birincisi, yeni yatırımlardır. Yeni yatırım türünde, farklı bir ülkenin piyasasında yeni bir üretim tesisi kurma faaliyeti gerçekleşmektedir. Bu yatırım türü, piyasada daha çok katma değer yarattığından ev sahibi ülkeler yeni yatırımlara sıcak bakmaktadır. Bazı durumlarda yapılan bu yatırım türü, DYSY yapılan ev sahibi ülkede uygulanan denetimler sonucu zorunlu olarak ta ortaya çıkabilmektedir. Diğer bir DYSY türü, şirket evlilikleridir. Şirket birleşmelerinde iki yöntem bulunmaktadır. Bunlardan ilki, benzer büyüklükteki iki şirket arasında piyasa gücü veya verimliliğini arttırmak amacıyla yapılan hisse senedi değişimi şeklinde bir yöntemdir. Şirket satın alma şeklinde gerçekleşen diğer yöntemde ise genellikle küçük bir şirketin varlıklarının önemli bir kısmı büyük bir işletme tarafından satın alınmaktadır. Yapılan DYSY türlerinden bir diğeri, özelleştirmelerdir. Özelleştirme, kamu kesimine ait kuruluşların hisse senetlerinin, yerli ve yabancı gerçek ya da tüzel kişilere satışının yapılması şeklinde tanımlanmaktadır (UNCTAD, 2013).

DYSY'nin gelişimini açıklayan bazı teoriler geliştirilmiştir. DYSY üzerine yapılmış teoriler, 1950'li yıllardan itibaren gelişmeye başlamıştır. Ürün devreleri teorisi, oligopolcü tepki teorisi, OLI modeli, yatay ve dikey entegrasyon yatırımlart teorisi bunlardan 
Bal, H. \& E.E. Akça (2016), "Doğrudan Yabancı Sermaye Yatırımlarının Belirleyicileri: Seçilmiş

Doğu Asya ve Pasifik Ülkelerinden Ampirik Bulgular”, Sosyoekonomi, Vol. 24(30), 91-111.

bazılarıdır. Ürün devreleri teorisi, Vernon (1966) tarafından ortaya atılmıştır. Vernon çalışmasında, "hayat döngüsü" kavramını tipik bir üretim sürecine dahil etmiştir. $\mathrm{Bu}$ çalışmada, bir üretim süreci, ürün geliştirme, olgunlaştırma ve standartlaştırma şeklinde üç ana evreye ayrılmıştır. Ürünün standartlaştırılması evresi burada doğrudan yabanc1 yatırımlar için önemli olan evredir. Ürün bu aşamada, yabancı ülkelerde yatırım konusu olabilecek aşamaya gelmiştir. Oligopolcü tepki modeli, Fredrick Knickerbocker tarafindan ortaya atılmıştır. $\mathrm{Bu}$ teoride doğrudan yabancı yatırımlar, oligopol piyasası bağlamında değerlendirilmektedir. Bu teoriye göre bazı firmalar, rakip olarak gördükleri firmaların dış piyasada yatırım yaparak söz konusu piyasaya hakim olmalarını engellemek amacıyla aynı piyasaya girmektedirler. DYSY'nin gelişimini açıklayan başka bir teori, John Dunning (1973) tarafindan ortaya atılan OLI modelidir. Bu teori, DYSY'nin belirleyicileri olan mülkiyet, yer ve içselleştirme üzerine yoğunlaşmıştır. Burada firma öncelikli olarak dış piyasada etkinlik sağlayacak üretim ayrıcalıklarına sahip olmalıdır. İkinci olarak yatırım yapılacak ülkede daha düşük maliyetli üretim ve taşıma maliyetlerinin düşük olması gibi avantajlara sahip olmalıdır. Son olarak ta firma, pazarlama, yönetim ve malın kontrolü gibi alanlarda mevcut bir iç ağa sahip olmalıdır. Kısacası piyasayı içselleştirme üstünlüğüne sahip olmalıdır. Dunning (1973), ülkelere yönelen DYSY belirleyicilerinin etkisinin ülkeden ülkeye değiştiğini ifade etmiştir. Buna göre DYSY; mülkiyet, yer ve içselleştirme kavramlarının daha güçlü olduğu ülkelere yönelecektir. Doğrudan yabancı yatırımları açılamaya çalışan önemli teorilerden bir diğeri, yatay ve dikey bütünleşme teorileridir. Yatay bütünleşme şeklinde gerçekleşen yatırımlar, yerli firmalarla rekabet edebilmek için ÇUŞ'ların sahip oldukları tekelci avantajları ürün farklılaştırmasında kullanması ve kendi ülkesinde ürettiği malları bu yolla dışarıda üretmesi olarak tanımlanmaktadır. Dikey bütünleşme yatırımları ise, ÇUŞ'lar tarafından üretilen nihai mal ve hizmetlerin üretim sürecinin birkaç aşamaya bölünmesi sonucunda bir malın üretiminin birkaç ülkede yapılması şeklinde gerçekleşmektedir. Dikey olarak adlandırılmasının sebebi, bir ürünün birçok ülkenin faaliyetleri sonucu oluşmasıdır. Dikey birleşmeler, ihracatın yüksek taşıma maliyetleri ve bazı engellere tabi olması sebebiyle hızlı bir şeklide yaygınlaşmıştır (Protsenko, 2003).

\subsection{Doğrudan Yabancı Sermaye Yatırımlarının Belirleyicileri}

Doğrudan yabancı sermaye yatırımları, ekonomik büyüme sürecinde önemli rol oynayabilmektedir. DYSY'nin artan önemi, DYSY'yi yurtiçine çekme konusunda ülkeler arasında rekabete yol açmıştır. Buna bağlı olarak söz konusu ülkeler daha fazla DYSY'yi yurtiçine çekmeye yönelik teşvik ve politika düzenlemelerini uygulamaya koymaktadırlar. DYSY'nin yurt içine girişini etkileyen faktörlerin belirlenmesinde, DYSY'nin bir ülkeye hangi amaçla gittiği büyük önem taşımaktadır. Bu kapsamda özellikle piyasa arayışında olan DYSY (market-seeking) ve piyasa arayışında olmayan DYSY (non-market seeking) arasındaki farkın ortaya koyulması önemlidir. Piyasa arayışında olan DYSY'nin başlıca amacı yurtiçi piyasalara hizmet etmektir. DYSY'nin bu türünde ev sahibi ülkede üretilen mallar yine o ülkenin yerel piyasalarında satılmaktadır. Dolayısıyla bu tür DYSY, ev sahibi ülkenin yüksek gelir düzeyine ve büyük piyasalara sahip olması gibi yurtiçi talebi artırıcı faktörlerden etkilenmektedir. Piyasa arayışında olmayan DYSY'de ise ev sahibi ülkede üretilen mallar yurt dışına satılmaktadır. Bu yüzden bu tür DYSY bir ülkeye giderken o 
ülkedeki talep faktörlerinin etkisi düşük düzeyde kalmaktadır (Asiedu, 2002: 109). Buradan yola çıkarak DYSY'nin potansiyel belirleyicilerinin, öncelikle bu yatırımların hangi amaçla yapıldığına bağlı olduğu sonucuna varılmaktadır. Literatürde, DYSY'nin büyük bir kısmının piyasa arayışı dolayısıyla yapıldığı belirtilmektedir. Özellikle yüksek milli gelir düzeylerine sahip ülkelere yönelen DYSY'nin bu amaçla yapıldığı vurgulanmaktadır (Janicki \& Wunnava, 2004; Choong \& Lam, 2010; Jadhav, 2012). Bu bağlamda, literatürdeki farklı çalışmalardan elde edilen bulgular doğrultusunda, ülkelere yönelen DYSY'nin temel belirleyicilerini şu şekilde özetlemek mümkündür:

- Piyasa Hacmi: DYSY’nın bir kısmı yeni piyasalara yani talebe ulaşmak amacıyla gerçekleşmektedir. Bu nedenle piyasa hacminin DYSY'yi pozitif etkilemesi beklenmektedir. Ayrıca büyük piyasalar ölçek ekonomileri sayesinde daha düşük maliyetli üretime olanak tanıyarak rekabet gücünü artırmaktadır (Vijayakumar vd., 2010). Özellikle iç piyasa için üretim yapacak DYSY için piyasa hacminin önemli bir belirleyici olduğu düşünülebilir. Piyasa hacminin göstergesi olarak genellikle GSYH veya kişi başına GSYH parametreleri kullanılmaktadır (Karagöz, 2007)

- Dışa Açıklık: Dışa açıklık bir ülkenin ticaret engellerini göstermesi bakımından önemlidir. DYSY, ihracat ve ithalat yönlü serbest ticaret politikalarının uygulandığı ülkelere yönelme eğilimindedir. Çoğunlukla ihracat ve ithalat toplamının GSYH'ya oranı şeklinde ölçülen dışa açıklık derecesindeki artışın daha fazla DYSY'yi yurt içine çekmesinin arkasında, DYSY'nin genellikle ticarete konu olan sektörlere yöneldiği düşüncesi yatmaktadır (Resmini, 2000; Choong \& Lam, 2010).

- Yı̆̆ılma Etkisi: DYSY, daha önce yapılan yatırım miktarından etkilenmektedir. Burada pozitif dışsallıklar ve sürü psikolojisinin etkisi beklenmektedir. Sürü psikolojisi daha önceki yapılan yatırımların yeni yatırımcılar tarafından uygun bir yatırım ortamının olduğu yönündeki değerlendirmelerinden ileri gelmektedir. Bazı yatırımlar daha önce yapılan yatırımların miktarını dikkate alabilmektedirler (Agiomirgianakis vd., 2003; Walsh \& Yu, 2010).

- Altyapı: Ulaşım ve iletişim ağları ile lojistik hizmetlerinin varlığı ve kalitesi, DYSY'nin yer seçiminde belirleyici faktörler arasında gösterilmektedir (Agiomirgianakis vd., 2003). Ulaşım ve haberleşme teknolojilerindeki gelişmeler, bir taraftan GOÜ'lerin mali piyasalarında işlem yapmayı kolaylaştırırken, diğer yandan ulaşım ve haberleşme teknolojilerindeki maliyetlerin düşmesine neden olmakta ve buna bağlı olarak sermayenin uluslararası hareketliliğini artırmaktadır (Kar \& Tatlısöz, 2008).

- Makroekonomik istikrar: İstikrarlı makroekonomik koşullara sahip olan ekonomilerin daha fazla DYSY'yi yurtiçine çekeceği belirtilmektedir. Ekonomik riskin de belirleyicisi olan makroekonomik istikrarı temsilen, yaygın olarak işsizlik oranı, enflasyon oranı, faiz oranı, döviz kuru, ve cari açık gibi göstergeler kullanılmaktadır (Vijayakumar vd., 2010). Makroekonomik istikrar, yerli ve yabancı tasarrufların yurtiçinde yatırıma dönüşmesine katkıda bulunmaktadır. Bir 
Bal, H. \& E.E. Akça (2016), "Doğrudan Yabancı Sermaye Yatırımlarının Belirleyicileri: Seçilmiş

Doğu Asya ve Pasifik Ülkelerinden Ampirik Bulgular”, Sosyoekonomi, Vol. 24(30), 91-111.

ülkede makroekonomik istikrarın olması; düşük enflasyon düzeyi, yüksek ve istikrarlı bir ekonomik büyüme, düşük işsizlik oranları, düşük reel faiz oranları ve bütçe açıklarının kontrol edilebilir düzeyde olması anlamına gelmektedir. Makroekonomik istikrar, ülke riskinin önemli bir unsurudur. Milli gelir ile yakından ilişkili olan makroekonomik istikrarın temel göstergelerini, enflasyon ve hükümetin genel bütçe dengesi oluşturmaktadır. Tarihsel olarak düşük bir enflasyon düzeyi ve ihtiyatlı maliye politikası uygulamaları, yabancı çevreler bakımından ülkenin kredibilitesini artırmakta ve yatırımları teşvik edici yönde işlev görmektedir (Karagöz, 2007; Kar \& Tatlısöz, 2008).

- Politik İstikrar: Ülkelerin DYSY kararlarında etkili olabilen bir diğer faktör politik istikrardır. Politik istikrarın olmadığı ülkelerde uygulanan ekonomi politikaları süreklilik göstermediği için, söz konusu ülkelere yapılacak yatırımların riski de daha fazla olacaktır. Bu durum potansiyel olarak yatırımc1 için ilave maliyet anlamına gelmektedir. Bu yüzden yatırımcı firmalar, DYSY kararı verirken politik iklim koşullarının daha istikrarlı olduğu ülkeleri seçmektedirler (Lall, 2003; Janicki \& Wunnava, 2004).

\subsection{Doğrudan Yabancı Sermaye Yatırımlarının Gelişim Seyri}

Asya-Pasifik bölgesi, yabancı yatırımcıların en çok tercih ettikleri bölgelerden birisidir. Bölgeye yapılan DYSY 2013 yılında 545.1 milyar dolardır. Alt bölgeler açısından değerlendirildiğinde bölge içerisinde en az yabancı yatırımı Pasifik bölgesi alırken, en çok yabancı yatırım ise Doğu Asya ülkelerine yapılmaktadır. Bölge ülkeleri açısından değerlendirildiğinde ise şu tespit ve değerlendirmelerde bulunulmaktadır (UNCTAD, 2013): DYSY'ye en açık ülkelerden birisi olan Avustralya, DYSY alan ülkeler sıralamasında dünyada yedinci sırada bulunmaktadır. Avustralya'nın bu başarısında rol oynayan başlıca faktörler olarak; hukuk sisteminin şeffaf ve güvenilir oluşu, liberal ekonomik politika uygulamaları ve özellikle son 15 yılda güçlü bir ekonomik büyüme sergilemesi gösterilmektedir. Ülkede DYSY'nin yöneldiği öncelikli sektörlerin başında; besin işleme endüstrisi, turizm, enerji ve yüksek katma değere sahip hizmetler sektörü gelmektedir. ABD'den sonra dünyanın ikinci en büyük DYSY alan ülkesi konumunda bulunan Çin'in bu yükselişinin başlıca nedenleri olarak; liberal politika uygulamaları, yüksek nüfusuyla dünyadaki en büyük iç pazara sahip olması, hızlı bir şekilde büyüyen bir piyasaya sahip olması, düşük iş gücü maliyetleri ve Çin'deki Batı eyaletlerinin gelişimi gösterilmektedir. Özellikle otomotiv ve dayanıklı tüketim malları sektörlerinde 1985 yılından sonra Çin'e yönelen DYSY'de ciddi artışların olduğu gözlenmektedir. Bu dönemde birçok ÇUŞ, düşük iş gücü maliyetlerinden ve yüksek yurtiçi talep avantajlarından yararlanmak için faaliyetlerini Çin'e taşımışlardır.

Güçlenen politik ve ekonomik istikrarı sayesinde bazı yatırım risklerini ortadan kaldıran Endonezya, DYSY girişi bakımından Doğu Asya ülkeleri arasında Çin, Hong Kong ve Singapur'dan sonra dördüncü sırada bulunmaktadır. Bununla birlikte, kredi maliyetinin yüksek oluşu, aşırı ve tahmin edilemez regülasyonların varlığı, gelişmemiş altyapı, terör riski ve yolsuzlukların varlığı gibi faktörler DYSY'yi caydırıcı yönde işlev görmektedir. Asya bölgesinde Çin'den sonra ikinci en büyük DYSY alan ülke durumunda bulunan Hong 
Kong, aynı zamanda bölgenin üçüncü en büyük DYSY yapan ülkesi konumundadır. Hong Kong'un stratejik konumu, serbest liman oluşu, çok basit ve teşvik edici bir vergi sistemine sahip olması ve gelişmiş bir altyapıya sahip olması gibi nedenler, DYSY'nin ülkeye yönelmesinde etkili olmuştur. Özellikle ileri teknoloji ve AR-GE alanlarında dünyada lider konumda bulunan ve bu alanlarda yabancı yatırım alan Japonya'nın sık sık doğal felaketlere tanık olması ise DYSY'yi itici yönde işlev görmektedir. Doğu ve Güneydoğu Asya bölgesinin beşinci en büyük DYSY alan ülkesi olan Malezya'nın bu performansında ülkenin yüksek nitelikli ve İngilizce konuşabilen işgücüne sahip olması büyük önem taşımaktadır. Ayrıca vergi indirimleri gibi çeşitli yollarla yabancı yatırımların güçlü bir şekilde teşvik edilmesi de Malezya'nın DYSY çekmesinde rol oynamaktadır. Diğer ülkelerle kıyaslandığında nispeten daha az DYSY alan Yeni Zelanda, başlıca ABD, Avustralya, Hollanda ve Japonya'dan yabancı yatırım almaktadır. Nitelikli erkek işgücüne sahip olması, ABD ile kültürel yakınlığı bulunması ve coğrafi konumu dikkate alındığında, Filipinler'e yapılan DYSY'nin beklenilen ölçüde olmadığı görülmektedir. Basit düzenleyici sistemi, politik istikrarı, vergi teşvikleri ve yolsuzluğun olmayışı sayesinde DYSY'nin cazibe merkezlerinden birisi olan Singapur, bu alanda dünyada sekizinci sırada bulunmaktadır. Ülkeye yapılan yabancı yatırımların başlıca ABD, Hollanda, İngiltere ve Japonya tarafından yapıldığı görülmektedir. Özellikle hızlı ekonomik gelişimi ile yeni bilgi ve haberleşme teknolojilerindeki başarısı sayesinde yabancı yatırım alan Güney Kore'nin düzenleme kalitesindeki başarısızlığ 1 ise daha fazla yabancı yatırımın ülkeye gelmesine engel teşkil etmektedir. DYSY, Tayland'ın ekonomik gelişim sürecinde önemli bir rol oynamıştır. Modern bir yasal sisteme sahip olması ve coğrafi konumu itibariyle Tayland, ÇUŞ'ların sıklıkla tercih ettikleri ülkelerden birisidir (UNCTAD, 2013). Şekil 1'de çalışmada ele alınan ülke ve dönem kapsamında DYSY akımlarının gelişimi gösterilmiştir.

Şekil 1'den son dönemlerde bölgeye gelen DYSY'nin büyük bir kısmının Çin, Hong Kong, Singapur ve Avustralya'ya yöneldiği görülmektedir. 2008 global kriz nedeniyle tüm ülkelere gelen DYSY'nin 2009 yılında düşüş eğilimine girdiği dikkat çeken bir diğer noktadır. 2013 yılında 123 milyar 911 milyar dolar doğrudan yabancı yatırım alan Çin, bu açıdan ABD’nin ardından dünyada ikinci sırada yer almaktadır. 2000-2013 dönemi kapsamında DYSY akımlarının en istikrarsız olduğu ülkelerin ise Avustralya ve Japonya olduğu anlaşılmaktadır. 


\section{Sekil: 1}

\section{0-2013 Dönemi Doğrudan Yabancı Sermaye Yatırımlarının Gelişimi (Milyar Dolar)}

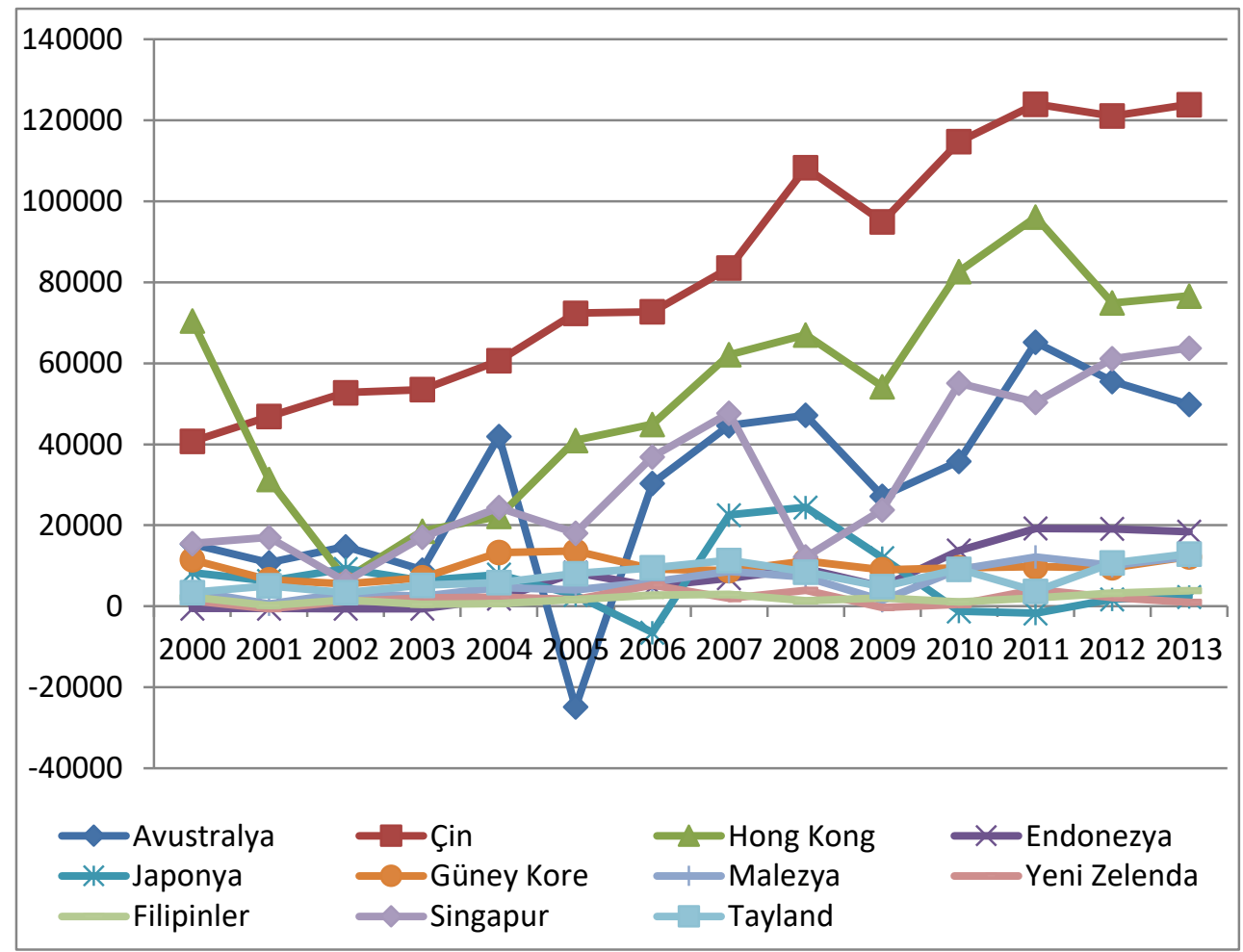

Kaynak: UNCTAD, 2014.

\section{Ampirik Literatür Özeti}

Doğrudan yabancı sermaye yatırımları üzerine yapılan ampirik çalışmalar temelde iki ana eksen etrafında toplanmaktadır. Çalışmaların bir kısmında DYSY'nin iktisadi gelişme üzerine etkileri araştırılırken, diğer bir kısmında ise DYSY'yi yurt içine çeken (ya da iten) faktörlerin belirlenmesi amaçlanmaktadır. Literatürde DYSY'yi yurt içine çeken faktörleri belirlemeye yönelik birçok çalışma bulunmakla birlikte, çalışmalardan elde edilen sonuçlarda ortak bir görüş birliğine varılamamıştır. Bunda ülkelerin farklı iktisadi yapılara sahip olmalarının yanı sıra, çalışmalardaki bakış açılarının, kullanılan yöntemlerin, örneklem seçimlerinin ve analiz araçlarının farklı olması da etkili olmaktadır. Bu bakımdan, DYSY'nin belirleyicilerini incelemeye yönelik ampirik çalışmalara rehberlik edecek teorik bir yapının eksikliği ortadadır (Karagöz, 2007: 938).

DYSY'nin belirleyicilerini test etmeye yönelik klasik model; mülkiyet, yer ve uluslararasılaşma (OLI) paradigmasına dayalı kapsamlı analizler sunan Dunning (1973)'in 
Bal, H. \& E.E. Akça (2016), "Doğrudan Yabancı Sermaye Yatırımlarının Belirleyicileri: Seçilmiş Doğu Asya ve Pasifik Ülkelerinden Ampirik Bulgular", Sosyoekonomi, Vol. 24(30), 91-111.

çalışmasına dayanmaktadır. Ekonometrik yöntemlere dayalı ampirik çalışmalar ise 1980'li yıllardan sonra yaygınlık kazanmaya başlamıştır. Resmini (2000), üç aşamalı sabit etkiler panel veri yöntemini kullanarak, 1990-1995 dönemi kapsamında Merkezi ve Doğu Avrupa ülkeleri için DYSY'nin belirleyicilerini sektörel düzeyde araştırmıştır. Çalışmadan elde edilen genel sonuçlar şu şekildedir: DYSY'nin piyasa hacmine olan tepkisi pozitif olmakla birlikte sektörler arasında farklıdır ve geleneksel sektörlerde tepkinin şiddeti daha güçlüdür. Ücret farklılıklarının DYSY üzerindeki etkisi ölçek-yoğun ve yüksek teknolojili sektörlerde daha güçlüdür. Ticarete açıklık derecesinin DYSY üzerindeki etkisi sadece geleneksel sektörler için söz konusu iken, coğrafi yakınlığın DYSY üzerindeki etkisinin özellikle sermaye-yoğun ve yüksek teknolojili sektörlerde olduğu görülmektedir. Bengoa ve Robles (2002), çalışmasında, 1970-1999 yılları arasındaki 18 farklı Latin Amerika ülkesindeki ekonomik özgürlük, DYSY ve ekonomik büyüme arasındaki ilişkiyi analiz etmişlerdir. Panel veri analiz yönteminin kullanıldığı bu çalışmada elde edilen sonuçlara göre, ekonomik özgürlük, DYSY'ye ev sahipliği yapan ülkedeki DYSY akımını pozitif yönde etkilemiştir. Diğer bir sonuca göre ise DYSY'ye ev sahipliği yapan ülkedeki ekonomik büyüme ile DYSY akımı arasında pozitif yönlü bir ilişki mevcuttur. 1988-1997 dönemi kapsamında panel OLS yöntemini kullanan Asiedu (2002), GOÜ'lerde DYSY'nin belirleyicilerinin Sahra Altı Afrika (SSA) ülkelerini de aynı şekilde etkileyip etkilemediğini araştırmıştır. Çalışmadan elde edilen genel bulgular şu şekildedir: SSA'daki ülkeler bölgedeki diğer ülkelere göre coğrafya etkisinden (Afrika etkisi) dolayı daha az DYSY almaktadır. Daha yüksek sermaye getirisi SSA dişı ülkelerde DYSY'yi teşvik ederken, SSA ülkelerinde önemli bir etkisi yoktur. Ticarete açıklık derecesi hem SSA hem de SSA dişı ülkelerde DYSY'nin yurt içine girişini teşvik ederken, ticarete açıklık derecesindeki artışın marjinal faydası SSA dışı ülkelerde daha fazladır. Altyapı gelişiminin SSA dışı ülkelerde DYSY üzerinde önemli bir etkisi bulunurken, SSA ülkelerinde önemli bir etkisi bulunamamıştır. Elde edilen sonuçlardan şu politika çıkarımını yapmak mümkündür: Afrika ülkeleri ticaret rejimlerini liberalleştirdikçe bölgeye yönelen DYSY artmaktadır.

Agiomirgianakis vd. (2003), panel veri regresyon analizi yoluyla 1975-1997 dönemi kapsamında 20 OECD ülkesi için DYSY'nin belirleyicilerini analiz etmişlerdir. Çalışmadan elde edilen genel bulgular şu şekildedir: Ülkeye özgü nitelikleri göz ardı eden pooled OLS tahmincisinden elde edilen sonuçlara göre, beşeri sermayenin DYSY üzerinde pozitif ve anlamlı bir etkisi söz konusudur. Ayrıca piyasa hacminin, dış açıklık derecesinin ve yığılma etkisinin DYSY üzerinde oldukça önemli pozitif bir etkisinin olduğu sonucuna varılmıştır. Kamusal harcamalardaki artışın DYSY üzerinde pozitif etkisi olmasına rağmen, bu etkinin istatistiki olarak anlamsız olduğu saptanmıştır. Altyapı gelişimini temsil eden değişkenlerden tren yolu ağı istatistiki olarak anlamlı ve pozitif bir etkiye sahip iken, asfaltlanmış yol yüzdesi istatistiki olarak anlamsızdır. Türkiye'ye gelen DYSY'nin bölgesel belirleyicilerini koşullu logit modeli aracılığıyla inceleyen Deichman vd. (2003) yığılma etkisi, yerel finansal piyasaların derinliği, beşeri sermaye ve kıyı bölgelerine erişim parametrelerinin, DYSY'nin Türkiye'deki yer seçiminde önemli rol oynadıkları sonucuna varmışlardır. 1997 yılı için Avrupa Birliği ve Avrupa Birliği’ne aday 8 Merkezi ve Doğu Avrupa ülkesi arasındaki DYSY ilişkisini yatay-kesit yöntemiyle iki yönlü olarak inceleyen Janicki ve Wunnava (2004), ev sahibi ülkenin piyasa hacmi, ülke riski, dışa açıklık derecesi 
Bal, H. \& E.E. Akça (2016), "Doğrudan Yabancı Sermaye Yatırımlarının Belirleyicileri: Seçilmiş

Doğu Asya ve Pasifik Ülkelerinden Ampirik Bulgular”, Sosyoekonomi, Vol. 24(30), 91-111.

ve iş gücü maliyetleri parametrelerinin DYSY'nin temel belirleyicileri arasında yer aldığ bulgularını elde etmişlerdir.

1970-2005 dönemi için Türkiye'ye gelen DYSY'nın belirleyicilerini analiz eden Karagöz (2007), sadece yığılma etkisi ve dışa açıklık derecesinin DYSY girişleri üzerinde anlamlı etkileri olduğu sonucuna varmıştır. 1993-2002 dönemi kapsamında İspanya'nın sektörel düzeydeki panel verilerini kullanarak DYSY'nin belirleyicilerini inceleyen Rodriguez ve Pallas (2008), iş gücü verimliliği ve iş gücü maliyetleri arasındaki farklılıkların DYSY'nin İspanya'ya yönelmesinde belirleyici faktörler olduklarını ortaya koymuşlardır. 1980-2003 dönemi için Türkiye'ye gelen DYSY'nin belirleyicilerini araştıran Kar ve Tatlısöz (2008)'in çalışmalarından elde ettikleri bulgulara göre; uluslararası net rezervler, piyasa hacmi, dışa açıklık oranı, altyapı düzeyi ve yatırım teşvikleriyle DYSY arasında pozitif yönde bir ilişki tespit edilirken; reel döviz kuru ve iş gücü maliyetleri ile DYSY arasında ise negatif yönde bir ilişki gözlenmiştir.

1970-2006 dönemi kapsamında Malezya ekonomisi için DYSY'nin belirleyicilerini inceleyen Choong ve Lam (2010), DYSY'yi ülkeye çekici faktörler olarak; piyasa hacmi, dışa açıklık derecesi ve beşeri sermayenin gelişimi parametrelerine dikkat çekmektedir. 1975-2007 dönemi yıllık panel verileri kullanarak BRICS ülkelerine gelen DYSY'nı belirleyen faktörleri araştıran Vijayakumar vd. (2010) piyasa hacmi, iş gücü maliyeti, altyapı, döviz kuru ve gayri safi sermaye oluşumu parametrelerinin DYSY'nin temel belirleyicileri olduğunu tespit etmişlerdir. Buna karşın makroekonomik istikrar ve dişa açıklık parametrelerinin DYSY üzerinde herhangi bir etkisi olmadığı sonucuna varmışlardır. Romanya ekonomisi için DYSY ile ekonomik büyüme arasındaki ilişkiyi 1991-2009 dönemi kapsamında VAR modeliyle analiz eden Ludoşean (2012), DYSY değişkeninin büyüme üzerinde itici bir güç teşkil etmediği, ancak ekonomik büyümenin doğrudan yabanc1 yatırımları teşvik ettiği sonucuna ulaşmıştır. 2000-2009 dönemi kapsamında BRICS ekonomilerine ait panel verileri kullanarak DYSY'nin ekonomik, kurumsal ve politik belirleyicilerini ve bu belirleyicilerin karşılaştırmalı ağırlıklarını inceleyen Jadhav (2012), piyasa hacmi, dışa açıklık derecesi, hesap verebilirlik ve dile getirme, doğal kaynak donanımı ve enflasyon oranının DYSY'nin temel belirleyicileri olduğunu tespit etmiştir. Yazarın çalışmasından elde ettiği bulgulara göre piyasa hacmi, dışa açıklık derecesi ve enflasyon oranındaki artışların DYSY'yi teşvik ettiği; buna karşın hesap verebilirlik ve dile getirme ile doğal kaynak donanımı parametrelerindeki artışların DYSY'yi caydırdığı sonucuna varılmaktadır. Çalışmadan elde edilen bir diğer sonuç, DYSY'yi yurt içine çekme konusunda ekonomik faktörlerin kurumsal ve politik faktörlerden daha önemli olduğudur. 1970-2010 dönemi kapsamında eş bütünleşme ve hata düzeltme tekniklerini kullanarak Sudan için DYSY'nin belirleyicilerini analiz eden Ibrahim ve Hassan (2013)'ın çalışmalarından elde ettikleri bulgulara göre; piyasa hacmi, enflasyon oranı, döviz kuru ve yatırım teşvik politikası parametreleri, DYSY'nin temel belirleyicileri arasında yer almaktadir.

Literatür özetinden de anlaşılacağı üzere DYSY'nin belirleyicileri konusunda ortak bir görüş birliğine varılamamıştır. Gittikçe sayıları artan bu çalışmalara rağmen, özellikle son yıllarda DYSY bakımından dikkat çeken Doğu Asya ve Pasifik ülkeleri üzerine panel 
veri yönteminin de kullanıldığı çalışmaların sayısı görece azdır. Literatürdeki bu boşluktan yola çıkarak hazırlanan bu çalışma, güncel veri setleri ve analiz teknikleriyle ampirik literatüre katkı sağlamayı amaçlamaktadır.

\section{Veri Seti, Metedoloji ve Ekonometrik Model}

Çalışmada, Doğu Asya ve Pasifik bölgesini temsilen 11 ülke (Avustralya, Çin, Endonezya, Filipinler, Güney Kore, Hong Kong, Japonya, Malezya, Singapur, Tayland ve Yeni Zelenda)'nin 2000-2013 dönemi yıllık verileri kullanılmıştır. Böylece 11 (N) ülke ve 14 yıl (T) olmak üzere 154 gözlem sayılı dengeli panel verileri analiz edilmiştir. Ülke seçiminde Dünya Bankası sınıflandırması dikkate alınmıştır. Literatürde DYSY'nıin belirleyicilerini açıklamak için farklı birçok değişken kullanılmaktadır. Bunların bir kısmı DYSY ile ilgili teorilerin sunduğu hipotezlere dayanırken; bir kısmı ise sezgisel olarak DYSY girişlerini açıklayabileceği düşünülen değişkenlerdir. $\mathrm{Bu}$ çalışmada DYSY göstergesini temsilen, yurt içine giren net DYSY akımları değişkeni alınmıştır. Bu bağımlı değişkeni açıklayıcı etkileri incelenen piyasa hacmini temsilen GSYH, dışa açıklık derecesinin bir ölçütü olarak ihracat ve ithalat miktarları toplamının GSYH içindeki payı, yı̆̆ılma etkisinin bir göstergesi olarak bir önceki yılda yurt içine giren net DYSY miktarı, makroekonomik istikrarın bir göstergesi olarak enflasyon oranı, altyapıyı temsilen sabit telefon hattı sayısı ve politik istikrarın bir göstergesi olarak ta huzur ve politik istikrar endeksi değişkeni kullanılmıştır.

Çalışmada kullanılan veriler ile açıklamalarına ve veri kaynaklarına ilişkin bilgiler Tablo 1'de özetlenmiştir. Serileri olası değişen varyans ve kısmen de otokorelasyona karş1 koruyabilmek için enflasyon oranı ve ticarete açıklık değişkenleri haricindeki tüm değişkenlerin doğal logaritmik dönüşümü yapılmış ve o şekilde analize dâhil edilmiştir.

Tablo: 1

Kullanılan Değişkenler, Açıklamaları ve Veri Kaynakları

\begin{tabular}{|c|c|c|c|}
\hline Zaman Serisi & Değişken & Açıklama & Kaynak \\
\hline $\begin{array}{c}\text { Doğrudan Yabancı } \\
\text { Sermaye Yatırımı }\end{array}$ & RDYSY & $\begin{array}{c}\text { Yurt İçine Giren Net Reel DYSY Akımları, TUFE Bazlı, } \\
2010=100\end{array}$ & $\begin{array}{c}\text { WB-WDI, } \\
2015\end{array}$ \\
\hline Piyasa hacmi & $R G D P$ & Reel GSYH, TÜFE Bazlı, 2010=100. & $\begin{array}{c}\text { WB-WDI, } \\
2015\end{array}$ \\
\hline Dışa Açılklk & OPEN & Mal ve Hizmet İhracat ve İthalat Toplamının GDP \\
İçindeki Payı (\%) & $\begin{array}{c}\text { WB-WDI, } \\
2015\end{array}$ \\
\hline Yığılma Etkisi & RAGG & $\begin{array}{c}\text { Yurt İçine Giren Net Reel DYSY Akımlarının Gecikmeli } \\
\text { Değeri, TUFE Bazlı, 2010=100 }\end{array}$ & $\begin{array}{c}\text { WB-WDI, } \\
2015\end{array}$ \\
\hline Makro Ekonomik İstikrar & $I N F$ & TÜFE'deki Yüzdelik Değişim (\%) & $\begin{array}{c}\text { WB-WDI, } \\
2015\end{array}$ \\
\hline Altyapı & TEL & 100 Kişi Başı̧na Düşen Sabit Telefon Hattı Sayısı & $\begin{array}{c}\text { WB-WDI, } \\
2015\end{array}$ \\
\hline Politik İstikrar & POL & Şiddet/terör bakımından huzur ve politik istikrar & $\begin{array}{c}\text { WB-WGI, } \\
2015\end{array}$ \\
\hline \multicolumn{2}{|c|}{ Modifikasyon Verileri } & TÜFE, Nüfus & $\begin{array}{c}\text { WB-WDI, } \\
2015\end{array}$ \\
\hline
\end{tabular}


Çalışmada, DYSY'nin belirleyicileri 2000-2013 dönemi panel veri setleri kullanılarak analiz edilmiştir. $N$ sayıda birimin ve her birime ait $T$ sayıda gözlemin olduğu panel veri setleri için genel olarak doğrusal panel veri modeli kısaca şu şekildedir:

$$
\begin{aligned}
& Y_{i t}=\beta_{0 i t}+\sum_{k=1}^{K} \beta_{k i t} X_{k i t}+u_{i t} \quad(i=1,2, \ldots, N ; t=1,2, \ldots, T) \\
& y_{i t}=\alpha+\mathrm{X}_{\mathrm{it}} \beta+\mathrm{u}_{\mathrm{it}} \\
& \mathrm{u}_{\mathrm{it}}=\mu_{i}+\mathrm{V}_{\mathrm{it}}
\end{aligned}
$$

Burada $i$ birimleri, yani yatay kesit boyutunu, $t$ ise zaman boyutunu ifade etmek üzere, $\beta_{0 i t}, K x 1$ boyutlu parametreler vektörünü, $X_{k i t} k$ 'ınc1 açıklayıcı değişkenin $t$ zamanında $i$ 'inci birim için değerini ve $Y_{i t}$, bağımlı değişkenin $t$ zamanında $i$ 'inci birim için değerini göstermektedir. Panel veri analiz prosedüründe, her bir birimde gözlenemeyen bireysel etkiler ortaya çıkabilmektedir. Denklik 3'teki $\mu_{\mathrm{i}}$ gözlenemeyen bireysel etkileri ifade ederken, $v_{\text {it }}$ geriye kalan hata terimini ifade etmektedir. Modeldeki sabit terimin $(\alpha)$ birimden birime değişmesi, bireysel heterojenity olarak adlandırılmaktadır. Panel veri modelleri, parametrelerin birim ve/veya zaman göre değer almasına bağlı olarak farklı biçimlerde sınıflandırılabilmektedir. Eğer panel verideki gözlenemeyen bireysel etkiler, hata terimi gibi, tesadüfi bir değişken olarak ele alınırsa rassal etkiler; her bir yatay kesit gözlem için tahmin edilen bir parametre olarak ele alınıyorsa sabit etkiler söz konusu olmaktadır. Sabit etkiler modelinde birimlerin davranışlarındaki farklılıklar sabit terimdeki farklılıklarla temsil edilmektedir. Bu modelde, gözlenemeyen bireysel etkilerin modelde yer alan açıklayıcı değişkenler ile ilişkili olduğu kabul edilmektedir. Bu nedenle birimler arasındaki farklılıklar regresyon fonksiyonunda parametrik olarak modellenmektedir. Sabit etkiler ve rassal etkiler modellerinin yanı sıra, modeldeki bütün yatay-kesitler için ortak bir sabit terim tahmin eden havuzlanmış en küçük kareler modeli bulunmaktadır. Bu modelde her bir yatay kesite ait belirli etkileri yansıtan kukla değişkenler olmadan bütün ülkelerin verileri bir havuzda toplanmakta ve bağımsız değişkenlerin bağımlı değişken üzerindeki etkileri incelenmektedir (Sayılgan \& Süslü, 2011, s. 84). Sabit etkiler modeli tahmincileri sadece grup ortalamalarından sapmalara bağlı olduğundan bazen grup-içi tahminciler olarak adlandırılmaktadır. Eğer yatay-kesit etkileri ile bağımsız değişkenler arasında korelasyon varsa, yatay-kesit etkileri ile grup ortalamaları arasında da korelasyon olacaktır. Bu durumda, grup içi tahminciler tutarlı olsa bile, havuzlanmış örneğe ilişkin EKK tahmini tutarsız olacaktır. Eğer sadece grup ortalamaları arasında bir varyasyon varsa gruplar arası tahminci kabul edilebilir olmakla birlikte, bu kez eğer yatay kesit hataları ile bağımız değişkenlerin grup ortalamaları arasında korelasyon varsa uyumsuzluk ortaya çıkacaktır (Hsiao, 2003; Baltagi, 2005).

Sabit etkiler ve rassal etkiler modellerinin her ikisinde de grup etkisi ve/veya zaman etkisinin varlığına bağlı olarak tek-yönlü ya da çift-yönlü modeller ortaya çıkabilmektedir. Tek-yönlü sabit etkiler (grup etkisi) modelinin gösterimi şu şekildedir (Brooks, 2008): 


$$
y_{i t}=\alpha+\beta \mathrm{X}_{\mathrm{it}}+\mu_{\mathrm{i}}+\mathrm{v}_{\mathrm{it}}
$$

Denklem 4'te yer alan $\mu_{\mathrm{i}}$, yatay-kesit olarak bağımlı değişkeni etkileyen, fakat zamanla sabit kalan tüm değişkenleri temsil etmektedir. Bu model her bir yatay kesit için kukla değişkenler kullanılarak tahmin edilmektedir. Modelde sabit terimin olması durumunda kukla değişken tuzağına düşmemek için (n-1) tane kukla değişken kullanılmaktadır. Tahmin sonucu elde edilen sabit terim katsayısının tüm yatay-kesitler için aynı olması durumunda havuzlanmış EKK, farklı olması durumunda ise tek-yönlü sabit etkiler modelinin kullanılması uygun olmaktadır. Zaman etkisinin görüldüğü tek-yönlü sabit etkiler modelinin gösterimi ise şu şekildedir:

$$
y_{i t}=\alpha+\beta \mathrm{X}_{\mathrm{it}}+\lambda_{\mathrm{t}}+\mathrm{v}_{\mathrm{it}}
$$

Bu modelde bağımlı değişkenin ortalama değerinin zamanla değiştiği, fakat zamanın herhangi bir noktasında tüm yatay-kesitler için aynı olduğu varsayılmaktadır. Dolayısıyla zamanla değişen sabit terimin yatay kesitler arasında aynı olması söz konusudur. Denklem 5 'te yer alan $\lambda_{\mathrm{t}}$, zamanla değişim gösteren, fakat yatay kesitler arasında sabit olan ve bağımlı değişkeni etkileyen tüm değişkenleri temsil etmektedir. Bu model her bir zaman boyutu için kukla değişkenler kullanılarak tahmin edilmektedir. Son olarak grup etkisi ve zaman etkisinin modelde birlikte yer alması da söz konusudur:

$$
y_{i t}=\beta \mathrm{X}_{\mathrm{it}}+\mu_{1} \mathrm{D} 1_{\mathrm{i}}+\mu_{2} \mathrm{D} 2_{\mathrm{i}}+\mu_{3} \mathrm{D} 3_{\mathrm{i}}+\ldots+\mu_{N} \mathrm{DN} N_{\mathrm{i}}+\lambda_{\mathrm{I}} \mathrm{D} 1_{\mathrm{t}}+\lambda_{2} \mathrm{D} 2_{\mathrm{t}}+\lambda_{3} \mathrm{D} 3_{\mathrm{t}}+\ldots+\lambda_{\mathrm{T}} \mathrm{DT} \mathrm{T}_{\mathrm{t}}+\mathrm{V}_{\mathrm{it}}
$$

Denklem 6, grup ve zaman etkilerinin birlikte görüldüğü çift-yönlü sabit etkiler modelini ifade etmektedir. Bu modelde tahmin edilecek parametre sayıs $\mathrm{k}+\mathrm{N}+\mathrm{T}$ boyutundadır. Sabit etkiler modelinde olduğu gibi rassal etkiler modelinde de her bir yataykesit için farklı sabit terimler hesaplanmaktadır. Bununla birlikte rassal etkiler modelinde her bir yatay-kesit için hesaplanan sabit terim, ortak bir sabitten (tüm yatay-kesitler için aynı ve zamanla değişmeyen- $\alpha$ ) kaynaklanmaktadır. Tek-yönlü (grup etkisi) rassal etkiler modelinin gösterimi şu şekildedir:

$$
y_{i t}=\alpha+\beta \mathrm{X}_{\mathrm{it}}+\omega_{\mathrm{it}}, \quad \omega_{\mathrm{it}}=\varepsilon_{\mathrm{i}}+\mathrm{v}_{\mathrm{it}}
$$

Denklem 7'de yer alan $\varepsilon_{\mathrm{i}}$, zamanla değişmeyen, fakat yatay kesitler arasında farklı olan bir rassal değişkendir. $\varepsilon_{\mathrm{i}}$, her bir yatay kesite ait sabit terimin ortak sabit terimden $(\alpha)$ ne kadar saptığını göstermektedir. Zaman etkisinin görüldüğü tek-yönlü rassal etkiler modelinin gösterimi ise şu şekildedir:

$$
y_{i t}=\alpha+\beta \mathrm{X}_{\mathrm{it}}+\omega_{\mathrm{it}}, \quad \omega_{\mathrm{it}}=\varepsilon_{\mathrm{t}}+\mathrm{v}_{\mathrm{it}}
$$

Denklem 8'de yer alan $\mathcal{E}_{\mathrm{t}}$, zamanla değişim gösteren, fakat yatay kesitler arasında aynı olan bir rassal değişkendir. Yine sabit etkiler modelinde olduğu gibi rassal etkiler modelinde de grup ve zaman etkilerinin birlikte görüldügü çift-yönlü rassal etkiler modelinin 
ortaya çıkması olasıdır. Bu nedenle sayılan durumları dikkate alan $F$, LM, Honda ve Hausman gibi testlerin sonuçlarına göre en uygun model belirlenmektedir (Baltagi, 2005).

Çalışmanın teorik modeli, Asiedu (2002) ile Vijayakumar vd. (2010)'un çalışmalarından yola çıkarak şu şekilde oluşturulmuştur:

$$
R F D I=f(R G D P, O P E N, R A G G, I N F, \text { TEL, POL })
$$

Çalışmada, bütüncül bir yaklaşımla, açıklayıcı (bağımsız) değişkenlerin yurt içine giren net DYSY' yi (bağımlı değişken) hangi yönde ve ne derece etkilediklerinin incelenmesi amaciyla oluşturulan uzun dönem doğrusal panel regresyon modeli şu şekildedir:

$$
\begin{gathered}
R F D I_{i t}=\beta_{0}+\beta_{1} R G D P_{i t}+\beta_{2} O P E N_{i t}+\beta_{3} R A G G_{i t}+\beta_{4} I N F_{i t}+\beta_{5} T E L_{i t}+\beta_{6} P O L_{i t}+u_{i t} \\
(i=1,2,3, \ldots, 11 ; \quad t=2000,2001, \ldots, 2013) \\
(N=11) \quad(T=14)
\end{gathered}
$$

Burada; oransal değişkenler olan enflasyon oranı ve ticarete açıklık derecesi dışındaki diğer tüm değişkenler logaritmik formda yukarıda tabloda açıklandığı gibi iken, $i$ ülkeyi, $t$ yıll, $\beta_{0}$ bir sabiti ve $u_{i t}$ hata terimini göstermektedir. Teorik açıklamalar ve daha önceki çalışmalarda elde edilen bulgular doğrultusunda net olmamakla birlikte, piyasa hacmi, dışa açıklık derecesi, yı ğılma etkisi, altyapının gelişimi ve politik istikrarda yaşanan iyileşmelerin DYSY'yi olumlu yönde etkilemesi beklenirken $\left(\beta_{1}, \beta_{2}, \beta_{3}, \beta_{5}, \beta_{6}>0\right)$, makroekonomik istikrarı temsil eden enflasyon oranındaki bir artışın ise DYSY'yi olumsuz yönde etkilemesi $\left(\beta_{4}<0\right)$ beklenmektedir. Piyasa hacmini temsil eden reel GSYH'nın yüksek olduğu ülkelerde yatırımda bulunan firmalar potansiyel olarak daha yüksek getiri ve kar elde ettikleri için, reel GSYH'nın işaretinin pozitif olması beklenmektedir (Resmini, 2000; Lall, 2003; Jadhav, 2012; Janicki \& Wunnava, 2004; Choong ve Lam, 2010; Vijayakumar vd., 2010). Dış ticaret önündeki engelleri kaldıran ve ekonomide yaygın olarak liberal politika uygulamalarına yer veren ülkelerin daha fazla DYSY çekeceği belirtilmektedir (Resmini, 2000; Asiedu, 2002; Janicki ve Wunnava, 2004; Choong ve Lam, 2010; Jadhav, 2012). Daha önceki yapılan yatırımların yeni yatıımcılar tarafından uygun bir yatırım ortamının olduğu yönündeki değerlendirmelerinden dolayı yığılma etkisi ve DYSY arasında pozitif yönlü bir ilişki beklenmektedir (Resmini, 2000; Agiomirgianakis vd., 2003). Gelişmiş altyapılara sahip ülkelere yapılan yatırımlardan daha yüksek verimlilik elde edilebileceği için, DYSY'nin yer seçiminde altyapının gelişmişlik düzeyi önemli olabilmektedir (Asiedu, 2002; Vijayakumar vd., 2010). Makroekonomik istikrarın olduğu ülkelerde yatırımın risk payı daha düşük olacağı için, DYSY'nin makroekonomik istikrarın olduğu ülkeleri tercih edeceği belirtilmektedir (Janicki \& Wunnava, 2004; Vijayakumar vd., 2010). Politik istikrarın olduğu ülkelerde yabancı firmaların faaliyetlerini kısıtlayabilecek türde ayaklanmalar ile iç savaş olasılığının düşük olması ve huzur ortamının bulunması dolayısıyla DYSY ve politik istikrar arasında pozitif yönde bir ilişki bulunmaktadır. Ayrıca, politik istikrarın olduğu ülkelerde, yatırımın risk payı daha düşük olacağı için firmaların katlanacağı maliyet te daha düşüktür (Lall, 2003; Jadhav, 2012; Janicki \& Wunnava, 2004). 
Denklem 10'da belirtilen regresyon modeli, serilerin özelliklerine uygun olarak dengeli panel veri analizi prosedürü takip edilerek tahmin edilmiştir. Dengeli panelde her bir yatay kesit eşit sayıda zaman serisi gözlemine sahip olurken, dengesiz panelde ise bazı yatay kesitler diğerlerine göre daha az ya da daha fazla zaman serisine sahip olabilmektedir (Brooks, 2008: 490). Panel veri setleri geleneksel yatay-kesit ve zaman serilerine kiyasla bazı avantajlar sağlamaktadır: Panel veri, yatay kesit ve zaman serisi analizinin aksine, kapsadığı kesitleri heterojenliğe karşı kontrol etmektedir. Panel veri analizinin, yatay kesit ve zaman serisi analizi ile karşılaştırıldığında daha fazla değişkenlik gösterdiği ortaya çıkmaktadır. Bu değişkenlikten dolayı, regresyon modelindeki değişkenler arasında çoklu doğrusal bağlantı sorunuyla nispeten daha az karşılaşılmaktadır. Regresyon modelinin kapsadı̆̆ı gözlem sayısının da fazla olması sebebiyle serbestlik derecesi daha yüksek olmaktadır. Değişim dinamiklerinin etkilerinin ortaya konulması açısından daha uygun olan panel veri, zaman serisi ya da yatay kesit verisi yöntemiyle kolay bir şekilde fark edilemeyen etkilerin tanımlanmasında ve ölçülmesinde de daha etkindir. Zaman serisinin ve yatay kesit sayısının kısa olduğu durumlarda da panel veri analizi ile serbestlik derecesi artırılarak uygulama yapabilmek mümkündür (Baltagi, 2005: 4-6).

\section{Ampirik Bulgular}

DYSY'nin belirleyicilerinin tespit edilmesi amaciyla kurulan regresyon modelini tahmin etmeden önce, modelde yer alan değişkenlerle ilgili tanımlayıcı istatistiklere ve değişkenler arasındaki korelasyon ilişkisine bakılmış ve sonuçlar Tablo 2 ile Tablo 3 'te sunulmuştur.

Tablo: 2

Değişkenlere Ait Tanımlayıcı İstatistikler

$\begin{array}{ccccccc}\text { Değisskenler } & \text { Ortalama } & \text { Standart hata } & \text { Minimum } & \text { Maksimum } & \text { Jarque-Bera* } & \mathbf{N} \\ \text { RDYSY } & 7,592 & 1,996 & 0,001 & 9,497 & 0,000 & 154 \\ \text { RGDP } & 9,665 & 0,549 & 8,826 & 10,921 & 0,000 & 154 \\ \text { OPEN } & 135,93 & 125,57 & 20,258 & 458,332 & 0,000 & 154 \\ \text { RAGG } & 7,567 & 1,987 & 0,001 & 9,497 & 0,000 & 154 \\ \boldsymbol{T E L} \boldsymbol{I N \boldsymbol { F }} & 1,378 & 0,393 & 0,504 & 1,799 & 0,000 & 154 \\ \boldsymbol{I N F} & 2,771 & 2,589 & -3,693 & 13,109 & 0,000 & 154 \\ \boldsymbol{P O L} & 0,381 & 0,219 & -0,419 & 0,599 & 0,000 & 154\end{array}$

Tablo: 3

Değişkenler Arasındaki Korelasyon Matrisi

\begin{tabular}{|c|c|c|c|c|c|c|c|}
\hline & RDYSY & $R G D P$ & OPEN & $R A G G$ & $T E L$ & $I N F$ & POL \\
\hline RDYSY & 1 & & & & & & \\
\hline RGDP & 0,123 & 1 & & & & & \\
\hline OPEN & 0,238 & $-0,492$ & 1 & & & & \\
\hline$R A G G$ & 0,326 & 0,102 & 0,234 & 1 & & & \\
\hline$T E L$ & 0,178 & 0,250 & 0,239 & 0,246 & 1 & & \\
\hline$I N F$ & $-0,094$ & $-0,136$ & $-0,143$ & $-0,202$ & $-0,473$ & 1 & \\
\hline POL & 0,175 & 0,081 & 0,284 & 0,227 & 0,894 & $-0,511$ & 1 \\
\hline
\end{tabular}

Çalışmanın ekonometrik modelinin doğru metodolojiyle tahmin edilmesi amacıyla serilerin entegre derecelerinin belirlenmesi gerekmektedir. Literatürde bu amaçla kullanılabilecek çeşitli birim kök testleri mevcuttur. Panel birim kök testleri temel olarak, 
yatay kesit bağımlılığını dikkate almayan (1. nesil) ve yatay kesit bağımlılığını dikkate alan (2. nesil) testler olarak ikiye ayrılmaktadır. Ayrıca bazı birim kök testleri homojenlik varsayımından hareket ederken, bazıları ise heterojenlik varsayımından hareket etmektedir (Hsiao, 2003). Dolayısıyla çalışmaya uygun birim kök testlerinin yapılması amacıyla öncelikle yatay-kesit bağımlılı̆̆ı testleri ve homojenlik testi uygulanmıştır. Çalışmanın zaman ve yatay-kesit boyutu büyüklüğüne uygun olan Peseran (2004) ve Peseran vd. (2008) yatay-kesit bağımlılığı testleri ile Peseran ve Yamagata (2008) homojenlik testi sonuçları Tablo 4'te sunulmuştur.

Tablo: 4

\begin{tabular}{|c|c|c|c|c|c|c|c|}
\hline \multicolumn{8}{|c|}{ Yatay-Kesit Bağımlılığı ve Homojenlik Testleri } \\
\hline & RDYSY & $R G D P$ & OPEN & $R A G G$ & $T E L$ & INF & POL \\
\hline Peseran CD Test (2004) & 1,798 & $-1,338$ & $-1,128$ & 1,375 & $-0,512$ & $-0,611$ & $-0,963$ \\
\hline Peseran, Ullah ve Yamagata Bias-Adjusted & 0,104 & 0,336 & 0,763 & $\begin{array}{l}(2,00 J) \\
-0,605\end{array}$ & $\begin{array}{c}(0,988) \\
-0,988\end{array}$ & $-0,150$ & 1,947 \\
\hline LM Test (2008) & $(0,459)$ & $(0,368)$ & $(0,223)$ & $(0,725)$ & $(0,162)$ & $(0,560)$ & $(0,110)$ \\
\hline \multirow{2}{*}{$\begin{array}{c}\text { Peseran ve Yamagata (2008) } \\
\text { Homojenlik Testi }\end{array}$} & & \multicolumn{3}{|c|}{ Delta Tilde } & \multicolumn{3}{|c|}{ Delta Tilde adj } \\
\hline & & \multicolumn{3}{|c|}{$\begin{array}{l}-1,610 \\
(0,946)\end{array}$} & \multicolumn{3}{|c|}{$\begin{array}{l}-2,357 \\
(0,991)\end{array}$} \\
\hline
\end{tabular}

Not: Parantez içerisindeki değerler, $t$ istatistiklerinin olasıllk değerlerini göstermektedir.

Yatay-kesit bağımlılığg ve homojenlik testlerinden elde edilen sonuçlar, yatay-kesit bağımlılığının olmadığını ve yatay-kesitlerin homojen bir yapıda olduğunu göstermektedir. Buna göre çalışmada serilerin durağanlıklarının kontrolü için Levin, Lin ve Chu (2002) ile Breitung (2000) panel birim kök testleri uygulanmıştır. Birinci nesil panel birim kök testleri arasında yer alan ve çalışmanın amacına uygun olarak genel (ortak) birim kök sürecini dikkate alan bu testlerin sonuçları Tablo 5'de sunulmuştur.

\section{Tablo: 5}

\section{Panel Birim Kök Test Sonuçları}

\begin{tabular}{|c|c|c|c|c|}
\hline \multirow[t]{2}{*}{ Değişkenler } & \multicolumn{2}{|c|}{ Levin, Lin ve Chu (2002) } & \multicolumn{2}{|c|}{ Breitung (2000) } \\
\hline & Test. ist. & $P * *$ & Test. ist. & $P * *$ \\
\hline$R D Y S Y$ & $-4312 * *$ & 0,000 & $-3,177 * *$ & 0,000 \\
\hline$R G D P$ & $-2,437 * *$ & 0,007 & $-2,742 * *$ & 0,003 \\
\hline OPEN & $-2,042 * *$ & 0,021 & $-2,758 * *$ & 0,002 \\
\hline$R A G G$ & $-4,529 * *$ & 0,000 & $-5,562 * *$ & 0,000 \\
\hline$T E L$ & $-2,975 * *$ & 0,001 & $-3,464 * *$ & 0,000 \\
\hline$I N F$ & $-7,443 * *$ & 0,000 & $-7,231 * *$ & 0,000 \\
\hline$P O L$ & $-3,729 * *$ & 0,000 & $-2,037 * *$ & 0,021 \\
\hline
\end{tabular}

Not: Değişkenlere iliş̧kin Schwarz Bilgi Kriteri (SIC) 'ne göre maksimum gecikme uzunluğu trendsiz süreçlerde 02 , trendli süreçlerde 0-1 aralı̆̆ındadır. **\%5 anlam düzeyinde serilerin durağan olduğunu göstermektedir.

Tablo 5'ten regresyon modelinde yer alan değişkenlerin tamamının hem Levin, Lin ve $\mathrm{Chu}$ hem de Breitung test sonuçlarına göre birim kök içermediği, seviyede durağan olduğu anlaşılmaktadır. Buradan yola çıkarak uzun dönem doğrusal panel regresyon modelinin en küçük kareler yöntemiyle tahmin edilmesi uygundur. Bununla birlikte, merkezi limit teoreminden hareketle, bu çalışmada olduğu gibi panel verilerin zaman kesiti ( $\mathrm{T}=14)$ sınırlı olduğunda, birim kök testlerinin güvenilirliklerinin azaldığı göz ardı edilmemelidir (Hsiao, 2003). 
Çalışmada ele alınan regresyon modelini tahmin etmek için kullanılacak en uygun yöntemin belirlenmesi amacıyla yapılan testlerin sonuçları Tablo 6'da gösterilmiştir.

Tablo: 6

Sabit ve Rassal Etkiler Modeli Belirleme Testleri

\begin{tabular}{|c|c|c|}
\hline & $\boldsymbol{t}$ istatistikleri & $\boldsymbol{p}$ \\
\hline$F$ grup sabit etkiler modeli & $549,030^{* *}$ & 0,000 \\
\hline$F$ zaman sabit etkiler modeli & 0,891 & 0,565 \\
\hline$F$ çift yönlü sabit etkiler modeli & $2,706^{* *}$ & 0,000 \\
\hline$L M$ grup rassal etkiler modeli & $7,103^{* *}$ & 0,007 \\
\hline$L M$ zaman rassal etkiler modeli & 1,242 & 0,265 \\
\hline$L M$ çift yönlü rassal etkiler modeli & $8,344^{* *}$ & 0,015 \\
\hline Honda grup rassal etkiler modeli & $2,665^{* *}$ & 0,003 \\
\hline Honda zaman rassal etkiler modeli & $-1,115$ & 0,867 \\
\hline Honda çift yönlü rassal etkiler modeli & 1,096 & 0,136 \\
\hline Hausman Testi & 1,206 & 0,254 \\
\hline
\end{tabular}

Not: ** istatistiklerin \%5 düzeyinde anlamlı olduğunu göstermektedir.

Tablo 6'nın üst kısmındaki $F$ testi sonuçları, regresyon modelinin tahmin edilmesi amacıyla sabit etkiler modeli ile havuzlanmış EKK (pooled $O L S$ ) yöntemini karşılaştırmak için kullanılmaktadır. Bu teste Chow testi denilmektedir. $F$ testinden elde edilen sonuçlar, regresyon modelinin tahmininde tek yönlü sabit etkiler tahmincisinin (grup etkisi) kullanılması gerektiğini göstermektedir.

Sabit etkiler modeli test edildikten sonra, LM ve Honda testleri aracılığıyla rassal etkiler modeli ile havuzlanmış EKK (pooled $O L S$ ) yöntemi karşılaştırmaktadır. LM ve Honda testinden elde edilen sonuçlar, tek yönlü rassal etkiler tahmincisinin (grup etkisi) kullanılması gerektiğini göstermektedir.

Tablo: 7

Regresyon Modelinin Tek Yönlü Rassal Etkiler Modeli İle Tahmin Sonuçları

\begin{tabular}{|c|c|c|c|c|}
\hline Değişkenler & Katsayı & Standart Hata & $t$ istatistikleri (PCSE) & $P * *$ \\
\hline$R G D P$ & 1,069 & 0,335 & $3,187 * *$ & 0,002 \\
\hline OPEN & 0,005 & 0,001 & $3,635 * *$ & 0,000 \\
\hline$R A G G$ & 0,232 & 0,072 & $3,191 * *$ & 0,002 \\
\hline$T E L$ & $-0,868$ & 0,855 & $-1,015$ & 0,312 \\
\hline$I N F$ & 0,042 & 0,061 & 0,683 & 0,496 \\
\hline$P O L$ & 1,706 & 1,499 & 1,139 & 0,257 \\
\hline$C$ & $-4,768$ & 3,053 & $-1,562$ & 0,121 \\
\hline \multicolumn{3}{|c|}{$\begin{array}{c}R^{2}=0,185 \\
\text { Düzeltilmiş } R^{2}=0,152\end{array}$} & \multicolumn{2}{|l|}{$\begin{array}{c}\mathrm{F} \text { istatistiği }=5,583 * * \\
p=0,000\end{array}$} \\
\hline
\end{tabular}

Not: ${ }^{* *}$ istatistiklerin \%5 düzeyinde anlaml olduğunu göstermektedir. Rassal etki modelinin tahmininde SwamyArora yöntemi kullanılmıştır.

F, LM ve Honda testi sonuçları, tek yönlü sabit etkiler ve tek yönlü rassal etkiler tahmincilerinin uygulanabileceğini göstermektedir. Bu ikisinden hangisinin kullanılacağına karar vermek için Hausman testinden faydalanılmaktadır. Hausman testi sonuçları, regresyon modelinin tahmininde rassal etkiler tahmincisine işaret etmektedir. Buradan yola 
çıkarak uygulanan tek yönlü (grup etkisi) rassal etkiler modeli tahmin sonuçları Tablo 7'de gösterilmiştir.

Doğrusal regresyon modelinin önemli varsayımlarından birisi, sabit varyans varsayımıdır. Bu varsayıma göre hata terimi varyansı, bağımsız değişkenlerdeki değişimlere bağlı olarak değişmeyip aynı kalmalıdır. Hata terimi varyanslarının bağımsız değişkenlerle birlikte değişmesi durumunda değişen varyans sorunu ortaya çıkmaktadır. Doğrusal regresyon modelinin bir diğer önemli varsayımı da, hata teriminin birbirini izleyen değerleri arasında ilişki olmadığıdır. Hata terimleri arasında ilişki olması durumunda otokorelasyon sorunu ortaya çıkmaktadır (bkz. Hsiao, 2003: 74; Baltagi, 2005: 68). Mevcut çalışmanın regresyon modeliyle ilgili değişen varyans ve otokorelasyon test sonuçları Tablo 8'de gösterilmiştir.

Tablo: 8

Değişen Varyans ve Otokorelasyon Testi Sonuçları

\begin{tabular}{|l|c|c|}
\hline \multicolumn{2}{|c|}{ t istatistikleri } & $P^{* *}$ \\
\hline Değişen Varyans & \multicolumn{1}{|c|}{0} \\
\hline$L M h$ rassal etkiler modeli & $117,988^{* *}$ & 0,000 \\
\hline Otokorelasyon & & 0,025 \\
\hline$L M_{\mu \rho}$ rassal etkiler modeli & $7,342^{* *}$ & 0,023 \\
\hline$L M_{\mu / \rho}$ rassal etkiler modeli & $5,207^{* *}$ & 0,624 \\
\hline$L M_{\rho / \mu}$ rassal etkiler modeli & $6,048^{*}$ & \\
\hline
\end{tabular}

Not: **, istatistiklerin \%5 düzeyinde anlamlı olduğunu göstermektedir.

Tablo 8'de gösterilen $L M$ test sonuçlarına göre, tek yönlü rassal etkiler modeline göre değișen varyans ve otokorelasyon sorununun olduğu görülmektedir. Bu kapsamda regresyon modelinin, değişen varyans ve otokorelasyon sorunlarını da dikkate alarak dönem ağırlıklarına göre panel düzeltilmiş standart hata (panel-corrected standard error-PCSE) yöntemiyle tahmin sonuçları Tablo 9'da sunulmuştur.

Tablo 9. Regresyon Modelinin Değișen Varyans ve Otokorelasyon Kapsamında Tek Yönlü Rassal Etkiler Modeli İle Tahmin Sonuçları

\begin{tabular}{|c|c|c|c|c|}
\hline Değişkenler & Katsayı & Standart Hata & $\boldsymbol{t}$ istatistikleri $(\boldsymbol{P C S E})$ & $\boldsymbol{P}^{* *}$ \\
\hline$R G D P$ & 1,069 & 0,374 & $2,855^{* *}$ & 0,005 \\
\hline$O P E N$ & 0,005 & 0,001 & $3,286^{* *}$ & 0,001 \\
\hline$R A G G$ & 0,232 & 0,069 & $3,349^{* *}$ & 0,001 \\
\hline$T E L$ & $-0,868$ & 0,936 & $-0,927$ & 0,355 \\
\hline$I N F$ & 0,042 & 0,071 & 0,591 & 0,556 \\
\hline$P O L$ & 1,706 & 1,615 & 1,056 & 0,292 \\
\hline$C$ & $-4,768$ & 3,367 & $-1,416$ & 0,159 \\
\hline \multicolumn{2}{r|}{ Düzeltilmiş $R^{2}=0,152$} & F istatistiğ $\mathrm{i}=5,583^{* *}$ \\
$p=0,000$ & \\
\hline
\end{tabular}

Not: ** istatistiklerin \%5 düzeyinde anlaml olduğunu göstermektedir. Rassal etki modelinin tahmininde SwamyArora yöntemi kullanılmıştır.

Tek yönlü rassal etkiler modeliyle tahmin edilen regresyon modeli sonuçlarına göre, piyasa hacmi, dışa açıklık ve yığılma etkisi değişkenlerine ait katsayıların istatistiki olarak anlamlı oldukları görülmektedir. Altyapı, makroekonomik istikrar ve politik istikrar değişkenlerine ilişkin katsayıların ise istatistiki olarak anlamlı olmadıkları sonucuna 
varılmıştır. Tahmin edilen uzun dönem panel regresyon modeli sonuçlarına göre piyasa hacmi, dışa açıklık ve yığılma etkisi değişkenlerinde meydana gelen \%1'lik bir artış, yurt içine giren net DYSY'yi sırasıyla \%1,069, \%0,005 ve \%0,232 artırmaktadır. Altyap1, makroekonomik istikrar ve politik istikrar değişkenlerinde yaşanan gelişmelerin ise yurt içine giren net DYSY üzerinde herhangi bir etkisinin olmadığı anlaşılmaktadır. Elde edilen sonuçların teorik beklentilerle tutarlı olduğu görülmektedir. Bu sonuçlardan yola çıkarak, çalışmada ele alınan ülke grubu için DYSY'nin en önemli belirleyicisinin piyasa hacmi olduğu anlaşılmaktadır. Bunu sırasıyla yığılma etkisi ve ticarete açıklık derecesi takip etmektedir. Bu durum, Doğu Asya ve Pasifik bölgesine yapılan DYSY'nin daha çok yurtiçi piyasaları amaçlamaya yönelik olduğuna işaret etmektedir.

\section{Sonuç}

Doğrudan yabanc1 sermaye yatırımları, ülkelerin gerek duyduğu sermayeyi sağlamasının yanında üretim, ihracat, istihdam ve verimlilik artışları sağlayarak ve yönetim becerileri ile teknoloji transferini gerçekleştirerek ülkelerin ekonomik büyümesinde önemli rol oynayabilmektedir. Bu çalışmada, seçilmiş Doğu Asya ve Pasifik ülkeleri (Avustralya, Çin, Endonezya, Filipinler, Güney Kore, Hong Kong, Japonya, Malezya, Singapur, Tayland, Yeni Zelenda) için doğrudan yabancı sermaye yatırımlarının belirleyicileri, 2000-2013 dönemi panel verileri kullanılarak incelenmiştir. İlgili literatürden yola çıkarak doğrudan yabancı sermaye yatırımlarına yön vermesi beklenen faktörler; piyasa hacmi, dışa açıklık, makroekonomik istikrar, altyapı, yığılma etkisi ve politik istikrar olarak belirlenmiştir. Çalışmada doğrudan yabancı sermaye yatırımlarının belirleyicileri dengeli panel prosedürü takip edilerek analiz edilmiştir. Yapılan F, LM, Honda ve Hausman test sonuçlarına bağlı olarak, modelin tahmininde tek yönlü rassal etkiler tahmincisi kullanılmıştır. Çalışmadan elde edilen genel bulgular, söz konusu ülkelere gelen net doğrudan yabancı sermaye yatırımlarının piyasa hacmine, yığılma etkisine ve dişa açıklık derecesine bağlı olduğunu ortaya koymaktadır. Özellikle piyasa hacminin, doğrudan yabancı sermaye yatırımlarını çekme konusunda en önemli belirleyici olduğu anlaşılmaktadır. Çalışmadan elde edilen sonuçlar Choong ve Lam (2010) ile Jadhav (2012)'ın bulgularıyla örtüşmektedir. Buna karşın Vijayakumar vd. (2010), doğrudan yabancı yatırımları yurt içine çekme konusunda dışa açıklık derecesinin herhangi bir etkisinin olmadığı bulgularına ulaşırken, mevcut çalışmada ticarete açıklık derecesi önemli bir belirleyici olarak saptanmıştır. Buna göre, söz konusu ülkelerin yurtiçine giren net doğrudan yabancı sermaye yatırımlarını artırmak için, milli gelir düzeylerini ve ticarette serbestleşmeyi artırmaya yönelik aktif politikalar uygulamaları önerilmektedir.

\section{Kaynaklar}

Agiomirgianakis, G. \& D. Asterio \& K. Papathoma (2003), "The Determinants of Foreign Direct Investment: A Panel Data Study For the OECD Countries", City University Department of Economics Discussion Paper Series, No. 03/06, London, 1-18.

Asiedu, E. (2002), “On the Determinants of Foreign Direct Investment to Developing Countries: Is Africa Different?", World Development, 30(1), 107-119. 
Bal, H. \& E.E. Akça (2016), "Doğrudan Yabancı Sermaye Yatırımlarının Belirleyicileri: Seçilmiş Doğu Asya ve Pasifik Ülkelerinden Ampirik Bulgular”, Sosyoekonomi, Vol. 24(30), 91-111.

Baltagi, B.H. (2005), Econometrics Analysis of Panel Data, 3rd Edition, London: John Wiley \& Sons.

Bengoa, M. \& B. Sanchez-Robles (2003), "Foreign direct investment, economic freedom and growth: new evidence from Latin America", European Journal of Political Economy, Vol. 19, 529-545.

Breitung, J. (2000), “The Local Power of Some Unit Root Tsets for Panel Data”, Panel Cointegration and Dynamic Panels, Vol. 15, 161-177.

Brooks, C. (2008), Introductory Econometrics for Finance, Second Edition, Cambridge University Press, New York.

Choong, C. \& S. Lm (2010), "The Determinants of Foreign Direct Investment in Malesia: A Revisit”, Global Economic Review, 39(2), 175-195.

Deichman, J. \& S. Karidis \& S. Sayek (2003), "Foreign Direct Investment in Turkey: Regional Determinants", Applied Economics, 35(16), 1767-1778.

Dunning, J.H. (1973), “The Determinants of International Production”, Oxford Economic Papers, Vol. 25, 289-336.

Hsiao, C. (2003), Analysis of Panel Data, 2nd Edition, Cambridge: Cambridge University Press.

Ibrahim, Ö.A. \& H.M. Hassan (2013), "Determinants of Foreign Direct Investment in Sudan: An Econometric Perspective", The Journal of North African Studies, 18(1), 1-15.

Jadhav, P. (2012), "Determinants of Foreign Direct Investment in BRICS Economies: Analysis of Economic", Institutional and Political Faktor, Social and Behavioral Sciences, 37, 5-14.

Janicki, H.P. \& P.V. Wunnava (2004), "Determinants of Foreign Direct Investment: Empirical Evidence from EU Accession Candidates", Applied Economics, 36, 505-509.

Kar, M. \& F. Tatlısöz (2008), “Türkiye'de Doğrudan Yabancı Sermaye Yatırımlarını Belirleyen Faktörlerin Ekonometrik Analizi”, KMU İ̈BF Dergisi, Sayı 14, 1-23.

Karagöz, K. (2007), “Türkiye'de Doğrudan Yabancı Yatırım Girişlerini Belirleyen Faktörler: 19702005", Journal of Yaşar University, 2(8), 927-948.

Lall, P. \& D.W. Norman \& A.M. Featheartstone (2003), "Determinants of US Direct Foreign Investmentin the Caribbean", Applied Economics, 35(13), 1485-1496.

Levin, A. \& C.F. Lin \& C.S.J. Chu (2002), "Unit Root Tests in Panel Data: Asymptotic and FiniteSample Properties”, Journal of Econometrics, 108(1): 1-24.

Ludoşean, B.M. (2012), “A VAR Analysis of the Connection between FDI and Economic Growth in Romania", Theoretical and applied economics: GAER review, 19(10), 115-130.

Peseran, M.H. (2004), "General Diagnostic Tests for Cross Section Dependence in Panels", CESIFO Working Paper, No. 1229, 1-47.

Peseran, M.H \& T. Yamagata (2008), “Testing Slope Homogeneity in Large Panels", Journal of Econometrics 142, 50-93.

Peseran, M.H. \& A. Ullah \& T. Yamagata (2008), “A Bias-Adjusted LM Test of Error Cross Section Independence", Econometrics Journal, Vol. 11, 105-127.

Protsenko, A. (2003), "Vertical and Horizontal Foreign Direct Investments in Transition Countries", Ph.D. Thesis, Ludwig-Maximilians University Munich.

Resmini, L. (2000), "The Determinants of Foreign Direct Investment in the CEECs", Economics of Transition, Vol. 8(3), 665-689. 
Xosé A.R. \& J. (2008), "Determinants of foreign direct investment in Spain”, Applied Economics, 40(19), 2443-2450.

Sayılgan, G. \& C. Süslü (2011), "Makroekonomik Faktörlerin Hisse Senedi Getirilerine Etkisi: Türkiye ve Gelişmekte Olan Piyasalar Üzerine Bir İnceleme", BDDK Bankacılık ve Finansal Piyasalar Dergisi, 5(1), 73-96.

UNCTAD (2013), "World Investment Report 2013: Global Value Chains: Investment and Trade for Development", United Nations Publications, New York and Geneva.

Vijayakumar, N. \& P. Sridharan \& K.C.S. Rao (2010), "Determinants of FDI in BRICS Countries: A Panel Analysis", Journal of Business Science and Applied Management, 5(3), 1-13.

Wadhwa, K. (2011), "Foreign Direct Investment into Developing Asian Countries: The Role of Market Seeking, Resource Seeking and Efficiency Seeking Factors", Canadian Center of Science and Education, 6(11), 219-220.

Walsh, J.P. \& J. Yu (2010), "Determinants of Foreign Direct Investment: A Sectoral and Institutional Approach", IMF Working Papers, No. WP/10/187. 
Bal, H. \& E.E. Akça (2016), "Doğrudan Yabanıı Sermaye Yatırımlarının Belirleyicileri: Seçilmiş Doğu Asya ve Pasifik Ülkelerinden Ampirik Bulgular”, Sosyoekonomi, Vol. 24(30), 91-111. 